Impact Factor: 4.845(SJIF) Research Journal Of English (RJOE) Vol-5, Issue-1, 2020

www.rjoe.org.in An International Peer-Reviewed English Journal

ISSN: 2456-2696

Indexed in: International Citation Indexing (ICI), International Scientific Indexing (ISI), Directory of Research Journal Indexing (DRJI) Google Scholar \& Cosmos.

\title{
ISOLATIONOF WOMEN CHARACTERSIN STORIES
}

\author{
M.Maheswaran ${ }^{1}$ \\ Assistant professor, GITAM, Vishakapatnam,India \\ Dr.M.Rajaambethkar ${ }^{2}$ \\ Associate professor, KLEF, Vijayawda, India
}

\begin{abstract}
:
The article talks about a very unusual and sensitive topic of isolation of women in stories. Excerpts from 3 different stories have been engaged in such a way that the reader is provoked to think on the topic of isolation of women. Although dealt by many authors in their works to portray some interesting female characters, this article is an attempt to portray the character's emotional and mental character carefully without being drastic or dangerous. Three characters; Ratan from "The Postmaster", Anne Frank and Mei Misaki from "Another"; have been selected to depict different situations of isolation and how the character deals with it. The feelings of loneliness, companionship, fear, uncertainty, despair and hopelessness have been put in a very lucid way so as to incite an interest in the topic and sets the reader's mind thinking in a different dimension
\end{abstract}

Keywords: isolation, woman, story etc

Introduction

Isolation is a major human condition that has many psychological and philosophical implications. It has also however, been taken up as subject of interest in modern literature. Isolation is most commonly implemented into characters in novels in order to set up a character development arc for that particular character in question. It is not very uncommon to see a character being spiteful of others in a story at first and staying alone/ isolated, only to slowly open up as the story progresses. Isolation can also be depicted as a result of certain traumatic situations/events the character has gone through in the story; stories revolving around either of the world wars usually show this characteristic, PTSD being one of the most common reasons for the character suffering from isolation or any sort of mental disorder that has similar implications as isolating oneself.

Isolation comes in as a very sensitive topic, if handled poorly, it could potentially destroy any sort of interest the reader of the story could have had for the character. Hence it is an absolute necessity for the writer of the story to treat the theme of isolation very carefully and implement it into the characters properly. Just like a character in a novel or a poem, a well 
Impact Factor: 4.845(SJIF) Research Journal Of English (RJOE) Vol-5, Issue-1, 2020

www.rjoe.org.in An International Peer-Reviewed English Journal

ISSN: 2456-2696

Indexed in: International Citation Indexing (ICI), International Scientific Indexing (ISI), Directory of Research Journal Indexing (DRJI) Google Scholar \& Cosmos.

written isolated character can be taken up as a subject for a very interesting character study of that character.

Even though isolation is now becoming a very common theme being taken up by authors, we don't see a lot of women in stories that go through this phenomenon for us to have a discussion or character study about. However there are a few stories that do have the theme of isolation being implemented on women which I am going to talk about today. I'm going to be taking stories from novels, short stories and real biographies. So there's going to be a healthy mix of different women characters going through this phenomenon of isolation. Each of them, have their own way of dealing with it and have very unique personalities, something which I thought would keep this essay interesting every step of the way.

\section{EXPLANATION}

The first subject I want to talk about is a little girl named Ratan from the short story "The Postmaster", written by Rabindranath Tagore. The Postmaster features our protagonist, aptly named "The Postmaster", who was recently transferred to a distant rural village from the huge city of Calcutta. His new office seems to have only 2 rooms, his living quarters is nothing more than a "Thatched shed" near a stagnant pond. He also soon finds out that the locals aren't very social or friendly at all, which leaves him feeling very lonely in his new home. However, he did have a few companions, notably the little girl, Ratan.

Ratan was an orphan girl in the village. She could only very faintly remember her parents and her brother with whom she would play all day. Now, after becoming an orphan at such a young age (about 9), she longs to have a companion in a village that treats her like she's almost invisible. Living without friends or family made her want for a friend more and more, and now, with the arrival of the Postmaster, she finally had one.

Both, Ratan and the Postmaster had similar characteristics showcasing their mental condition and their feeling of loneliness; both faced very abrupt and sudden changes in their lives, both of them didn't have anybody they could call their "friend", and both of them were longing for a companion with whom they could share their thoughts with. This made their bond with each other all the more inevitable. Every night, Ratan used to coo for the Postmaster and light his pipe; the Postmaster used to ask her questions about her past, what she likes, etc, and she would do the same. Both of them grew closer and closer day after day.

What we see as the story progresses is how both of them handle their isolation very differently from each other. The Postmaster could not deal/accept the fact that he was far away from his actual home and wanted desperately to get transferred back despite of befriending Ratan. He could not live in the conditions that the people in the village were living in, he just couldn't adapt to it. On the contrary, Ratan, found a new friend in the 
Impact Factor: 4.845(SJIF) Research Journal Of English (RJOE) Vol-5, Issue-1, 2020

www.rjoe.org.in An International Peer-Reviewed English Journal

ISSN: 2456-2696

Indexed in: International Citation Indexing (ICI), International Scientific Indexing (ISI), Directory of Research Journal Indexing (DRJI) Google Scholar \& Cosmos.

Postmaster. She loved his presence around her as it made her forget her loneliness and he was someone who would listen to her every night. He was the one who taught her to read and she was extremely happy and ecstatic about learning even more from him. She took care of him when he got really sick and that event only made her bond with the Postmaster even stronger....at least for her.

Falling sick in that place was the breaking point for the Postmaster, he could not handle the place anymore and got himself transferred out of the place. He disregarded his bond with Ratan completely and decided to move out of the place, he couldn't bear staying away from his home, staying isolated like this. When he tells this news to Ratan, a very heartbreaking moment follows where the little girl literally begs him to either stay or take her with him. For both of which he said no because he didn't want to stay in that place anymore and he couldn't afford the living space and food for 2 people in a city. The Postmaster assures Ratan that a new Postmaster would come and take his place and take care of Ratan, however Ratan was heartbroken and wouldn't hear any of it. In the end, the Postmaster left for the city, leaving the heart broken little girl Ratan behind.

What the story "The Postmaster" depicts, is a very sad and heart wrenching story for sure, but it also depicts a version of isolation via Ratan. We see 2 characters in the story, suffering from alienation, but the way the 2 handle the same feeling is drastically different. The Postmaster wanted to go back to how things were, he didn't care about going forward with what he had but instead constantly complained about his current situation. Ratan on the other hand, she believed that the Postmaster was a new chapter in her life; she believed that she wasn't alone anymore, she believed that she wasn't just an invisible child of the village any longer. The Postmaster was the light at the end of the tunnel for Ratan; a light that disappeared all so suddenly disappeared one day as he left her for good.

This story heavily emphasises on the theme of isolation. Talking about Ratan exclusively, we see her grow closer and closer to someone who she thinks could be the key to taking all her loneliness away. This is one of the more common developments we see in a person suffering from extreme loneliness, after years of living alone, Ratan finally found someone she could be friends with, someone who listened to her, someone who made her feel loved again, but all those hopes went away with the Postmaster. Even in the end we see contrasting emotions shown by the Postmaster and Ratan, the Postmaster is ready to move on and leave the little girl behind because he has no obligation to her, whereas, Ratan isn't willing to move on and is in denial of the fact that he's leaving her for good. In this scenario, we can see how Rabindranath Tagore beautifully showed us the difference between how a mature mind such as the Postmaster's handles isolation, compared to the mind of a child like Ratan's. 
Impact Factor: 4.845(SJIF) Research Journal Of English (RJOE) Vol-5, Issue-1, 2020

www.rjoe.org.in An International Peer-Reviewed English Journal

ISSN: 2456-2696

Indexed in: International Citation Indexing (ICI), International Scientific Indexing (ISI), Directory of Research Journal Indexing (DRJI) Google Scholar \& Cosmos.

The story is just great from the plot perspective. The story particularly does a great job of fleshing Ratan's character throughout the plot, making the final goodbye even more emotional. Even though the ending wasn't the happiest of endings, the story does incite interesting character studies, especially about the mentality of a child compared to that of an adult when both are subjected to alienation or isolation.

Moving on, the next character I want to talk about is from the book "The Diary of a Young Girl"- by Anne Frank. Now, before I begin, yes, I know Anne Frank isn't exactly a "story" that was made up by an author per se, but given that it is indeed an autobiography of sorts, I have decided to include her diary in this discussion because of all the unique aspects of isolation it brings to the table.

Anne Frank is probably the most discussed Jew who lost her life in the Holocaust. Her story is very well known because of the discovery of her personal diary by her father after the war. On top of being a great insider on the terrible life the Jews had to live in during the war, it presents us a very close look of the mind of a young girl and how she dealt with the war and her family under very uncomfortable living conditions. The diary helps us understand the struggles she had to face, physically, mentally and most of all, how she faced an entirely different kind of isolation. Anne Frank started writing her diary a little while before the war and its effects on Jews took place. We can clearly see that the diary was a side hobby that she took up just because she received it as a birthday gift and wanted to make the best use of it. She even made up an imaginary friend "Kitty" that she would call her diary while she was writing. Once the Franks went into hiding inside a few concealed rooms behind some bookcases in the office where her dad worked, it becomes evident that Anne starting writing in her diary more and more frequently. This was the first sign that we see of her showing the symptoms of feeling lonely/isolated.... not exactly from her family, but rather from her friends and the world itself.

Change is very hard to adapt to, nobody likes change, especially really abrupt ones. So, a 12 year old girl who had to leave her house, her school, her friends, most of her belongings, almost everything behind to hide in an uncomfortable living space shared by 2 families had a very deep toll on her. From her writings in the diary, she didn't think too much of it at first, she just took the opportunity to write in the diary more frequently, which she clearly liked, but once time went on, she showed clear signs of loneliness, she missed her friends, her school...she missed being outside, hanging out with her friends, free. She often used to fill her diary every 3rd day or so, she also filled in some of her memories of the world outside. She held on to those memories very fondly as she was cut off from that very world due to all the persecutions happening all of the country. It is very difficult to even fathom what this poor girl had to face and go through in her time in hiding, even though she had family with her, she often felt left out and alone. She was scared to death every time she heard the 
Impact Factor: 4.845(SJIF) Research Journal Of English (RJOE) Vol-5, Issue-1, 2020

www.rjoe.org.in An International Peer-Reviewed English Journal

ISSN: 2456-2696

Indexed in: International Citation Indexing (ICI), International Scientific Indexing (ISI), Directory of Research Journal Indexing (DRJI) Google Scholar \& Cosmos.

bombardment of explosions at night, she was scared that she could never leave their hiding place, she was scared of so many things, but most of all, she was scared of being left out... by the world. She loved to hear the radio, and read the occasional newspapers that her dad managed to find, because she was curious to know about what she was missing out in her time in hiding.

What we see in Anne's case here is a very different form of isolation compared to that we saw in Ratan, where Ratan's isolation was more of a direct consequence of being alone and without anybody to call as a friend, Anne's isolation was more about being left out. She felt alone, not because she didn't have anybody to talk to, but because she couldn't do a lot of things she had dreamt of doing, she couldn't live a normal life, she couldn't eat proper food half the time, she had to spend very uncomfortable nights and she had to cover in her blanket every time the bombs were heard. She wanted to be free and she felt that nobody in her family could ever understand her; her parents wanted her to be strong and brave, but there was only so much she could endure as a kid, she felt as if she couldn't share her feelings with anybody and so bottled it all up....that is what made her feel isolated, not people, but rather the fear of helplessness.

Her feeling of being isolated all stems from her dreams and aspirations for the future, all being crushed in a single day just because of one man who deemed all Jews to be racially inferior to the Germans. There is no doubt that Anne Franks lived a very harsh life, unfair even, but what many people tend to overlook past all the general struggles and hardships faced by the Jewish families, is the mental toll all this had on them, especially the kids. Millions of Jews were left isolated in their very own country, had to hide from the society that was so cruel to them for no reason at all and Anne Frank went through all this trauma as a 12 year old girl. The feeling of being alienated from the world took a toll on her, many of her diary entries were straight up depressing to read, it is hard to see a child go through so much fear and loneliness. Yet, despite all this, Anne Frank hadn't given up on hope, she was optimistic that one day she will be free and could do everything that she ever wanted to do and the first thing being publishing her diary as a book. Even through so much agony and loneliness, she managed to stay strong and determined in hopes of a better day to come.

So far, we have seen isolation in its most common forms via Ratan (Being abandoned by family/friends), and isolation from the outside world via Anne Frank. In both stories, we see the same theme of isolation under different circumstances, and we see how differently the 2 girls in the stories deal with it. Being isolated/ alienated can take a hard toll on a person, the 2 girls in the stories above show us how this can affect a person's thinking and philosophy. Everybody deals with isolation in a very different way, but when it comes to literature, its so very common to see a case like Ratan, where a person slowly grows closer to other characters in a story (As it's a very easy to set up character arc for the character involved ); and many 
Impact Factor: 4.845(SJIF) Research Journal Of English (RJOE) Vol-5, Issue-1, 2020

www.rjoe.org.in An International Peer-Reviewed English Journal

ISSN: 2456-2696

Indexed in: International Citation Indexing (ICI), International Scientific Indexing (ISI), Directory of Research Journal Indexing (DRJI) Google Scholar \& Cosmos.

stories and documentaries showcase what Anne Frank( Jews in general) has gone through. However, what we don't see often, is a character that happily embraces their alienation from the world, a character who doesn't made being ignored by her peers, being isolated from society, but after a thorough search, I believe I finally found a novel that brings such a character to our books.

The next character I want to talk about with this unique trait is Mei Misaki from the Japanese horror novel "Another", written by Yukito Ayatsuji. The story of "Another" follows the life of a boy named Koichi Sakakibara, who upon transferring to the school Yomiyama Middle school finds out about the terrifying curse that's haunting the school. He finds out that every year a class from that school is cursed and all the students of that particular class die in very gruesome accidents similar to the "Final Destination" movies. Now, since the plot of the novel is very intriguing and very convoluted, I would first and foremost recommend you, the reader, to read it yourself. That being said, for the sake of this essay, I will have to spoil some plot twists and major story arcs for you, so here's your spoiler warning. Through a series of events we find out that way back in 1972, when the school just started, a very popular student of class "3-3" died and her friends and teachers were in so much pain and shock after her untimely death, they started to pretend that she didn't die. The entire year passed with them acting as if the deceased girl were still alive, but a very strange phenomenon happened right at the end of their academic year.

During the end of the year class photo, after the photo was developed and given to all the students of the class, they see the deceased girl in the photo, right alongside them. This obviously freaks all the students out. Ever since then, for an unknown reason, every student of class 3-3 dies a horrible and painful death, one by one, be it a car accident or getting pierced by the pointy end of an umbrella after slipping off the staircase, the deaths of all students of class 3-3 is inevitable. The novel explains why the school didn't shut down, why the class 3-3 still exists after all this and why parents and adults in general are oblivious to all this, but I can't explain all those reasons right now. Now, coming to the main part, the main character, Koichi finds a lonely girl who is ignored by everyone in class 3-3 to such an extent that it seems as though they think she doesn't exist at all. That girl's name was "Mei Misaki". Koichi tries to befriend her by talking to her but that only seems to aggravate the entire class and Mei herself shrugs him off. We find out later on that there is a "kind of working" solution to combat the deadly curse that was discovered by the students a few years prior, that solution being, ignoring one person of the class as though that person never existed in the first place. I know that it sounds really weird as I put it that way, but I cannot go into the details at the moment, so I really suggest you to read the novel yourself.

So, with the plot out of the way, we now know that Mei is ignored by the entire class and in turn doesn't have a single friend and all in the hopes of avoiding their deaths due to an 
Impact Factor: 4.845(SJIF) Research Journal Of English (RJOE) Vol-5, Issue-1, 2020

www.rioe.org.in An International Peer-Reviewed English Journal

ISSN: 2456-2696

Indexed in: International Citation Indexing (ICI), International Scientific Indexing (ISI), Directory of Research Journal Indexing (DRJI) Google Scholar \& Cosmos.

ancient curse. We as readers expect Mei to be emotionally weak or even vulnerable, but to our surprise, Mei actually embraces her isolated condition. Even though Koichi, our protagonist, tries to befriend her, we never truly see her reciprocate his feeling as she constantly ignores his attempts for starting a friendship. We see Mei being very comfortable being treated like she doesn't even exists, it makes her give off a very mysterious vibe in the novel.... spooky even. This is a very unusual symptom for an alienated character to show; acceptance of their state and embracing it. Even though literally everybody in her class pretends as though she doesn't even exist, she doesn't show the slightest bit of grief because of it. She seems almost emotionless, cold...almost like her body is a doll without a soul (This is actually contrasted in the novel with her creepy obsession for dolls). Mei is just a young girl studying in a middle school (With an ancient and deadly curse, sure) and she's being treated like trash by all her classmates and she shows no emotion. As the story progresses, she believes that she is the reason all these terrible deaths are occurring, and she in fact is a cursed child, she shows just a very tiny bit of remorse when she opens up to Koichi, but that's it, throughout the rest of the novel she seems to be emotionless, accepting her isolated self as though being alienated by her peers in school means nothing to her.

The type of behaviour Mei shows is not exactly normal, even though isolated people can show symptoms of insanity or depression, Mei is not entirely depressed or insane, she makes rational and logical decisions throughout the story and doesn't show any emotional vulnerability. She just.....is okay, with being alone. I am pretty sure that the author didn't put in any research while writing her mentally disturbed character (Then again, this novel is not about Mei's alienation, it's about the curse and the gore). So, the way Mei is dealing with isolation is one of the most unique ways I've ever seen someone like her being portrayed in a book. I have no proper explanation as to why Mei thinks and does things the way she does, but I had to include her in this essay to showcase this very unique way of handling an isolated character in a story. "Another" tell us a gripping story about a cursed middle school class, but it ends up giving us a very intriguing character to study about. Mei's unique perspective to the situation she is in and her way of handling isolation by accepting it and merging it into her lifestyle as though nothing's wrong brings to the table of literature a very, very, very new and unique take on a character who is isolated from the rest of the world/ their peers. This story is a must read and I recommend it to anyone who is a fan of psychological horror, or horror in general.

\section{CONCLUSION}

These were just 3 examples of women in stories who were isolated/ alienated from/by the world/their peers. I decided to include them, because I wanted them to represent the different ways women in stories/novels react to such a condition, isolation can have a serious mental toll on a person and we can see the same reflect onto these 3 women. Each having their own way of dealing with it, be it with optimism, or depression or straight up accepting and 
Impact Factor: 4.845(SJIF) Research Journal Of English (RJOE) Vol-5, Issue-1, 2020

www.rjoe.org.in An International Peer-Reviewed English Journal

ISSN: 2456-2696

Indexed in: International Citation Indexing (ICI), International Scientific Indexing (ISI), Directory of Research Journal Indexing (DRJI) Google Scholar \& Cosmos.

embracing their loneliness. I am sure there are many other characters that could have been included here, but I think these 3 do a really good job of trying to get my idea and thoughts across. The theme of isolation of characters in general in literature is slowly growing, as I said earlier, an isolated character can be used for a character arc for them to be set up, the theme of isolation can also be used to enhance a character's terrible condition. The theme of isolation can be used in a multitude of ways in modern literature to deliver very interesting stories to the reader, if handled correctly and delicately of course. Although this theme/topic of isolated women characters or characters in general might sound bleak, the inclusion of such themes into stories and novels shows us how our taste in literature has grown over time and how we are willing to accept more thought provoking stories rather than just blind and tasteless drama like back in the day. This shows us that literature is something that constantly evolves and explores new themes and topics to write stories about, stories to read, stories to enjoy, stories to get inspired and stories to simply, intrigue. The world of literature is filled with stories and stories and stories, and its complex themes like "Isolation of characters" that push the envelope and the boundaries of our writer's imagination to the next level to deliver us mature, more complex and better stories to read.

\section{Reference}

- https://www.shortstoryproject.com/story/the-postmaster/

- https://en.m.wikipedia.org/wiki/Anne_Frank "Another"- Novel written by Yukito Ayatsuji 